Agro-Science Journal of Tropical Agriculture, Food, Environment and Extension Volume 21 Number 1 (January 2022) pp. $98-102$

ISSN 1119-7455

\title{
FACTORS INFLUENCING INPUT DEALERS' PERFORMANCE OF EXTENSION ROLES TO FARMERS IN YOBE STATE OF NIGERIA
}

\author{
*10woade E.O., ${ }^{1}$ Abubakar M., ${ }^{1}$ Abdulhakeem A.L. and ${ }^{2}$ Akinwale J.A. \\ ${ }^{1}$ Department of Agricultural Economics \& Extension, Federal University Gashua, Yobe State, Nigeria \\ ${ }^{2}$ Department of Agricultural Extension \& Communication Technology, \\ Federal University of Technology, Akure, Ondo State, Nigeria \\ *Corresponding author's email: toyinowoade1970@gmail.com
}

\begin{abstract}
The study examined factors influencing input dealers' performance of extension role to farmers in Yobe State of Nigeria. Multi-stage sampling procedure was adopted in selecting 86 input dealers. Primary data were collected from them on socioeconomic characteristics, performance of extension roles, sources of agricultural knowledge and training using a structured questionnaire. Descriptive and inferential statistics were used to analyze data. Results showed that input dealers were mostly males (98.8\%); young and agile with mean age of 41.8 years, $44.2 \%$ had tertiary education but $86.0 \%$ had no agricultural qualifications. Although input dealers' performance of extension roles was high (55.8\%), they had low training (68.6\%) to boost performance. Significant relationships existed between performance of extension roles and type of trade $\left(\chi^{2}=25.135, p<0.05\right)$ and membership of input dealers association $\left(\chi^{2}=12.550, p<0.05\right)$. Also, a significant positive correlation existed between performance of extension roles and training received $(r=0.33, p<0.05)$ and sources of agricultural knowledge $(r=0.25, p<0.05)$. It was recommended that input dealers should be strengthened to perform extension roles by enhancing their training and access to sources of agricultural knowledge via institutionalized research, extension, input companies and input dealers' linkage.
\end{abstract}

Key words: factors, input dealers, performance, extension role

\section{INTRODUCTION}

The primary role of Nigerian agricultural extension service, which is to build the capacity of farmers to boost agricultural productivity, has currently dwindled. The activities of the main agricultural extension organ of the governments, that is, the Agricultural Development Projects (ADPs) have been limited as a result of inadequate personnel, high extension-farmer ratio, irregular payment of salaries, poor provision of logistics and staff training (Agbamu and Okagbare, 2005; Ogunlade et al., 2012; Haruna and Abdullahi, 2013). Evidently, effective coverage of the smallholder farmers with diverse crops and livestock enterprises is an enormous task for the public extension considering the current challenges. However, the pluralistic extension delivery system comprising the activities of other actors such as farmer organizations, nongovernmental organizations, input companies/ dealers, produce-buying companies and private extension providers (Anderson, 2008) need to be exploited. Meanwhile, lack of national extension policy frame work in Nigeria has hindered full utilisation of potentials of aforementioned actors in providing advisory services to smallholder farmers (Madukwe, 2008). While peculiar nature of each of the actors determines the form of advisory service render to the smallholder farmers, the significance of inputs to any agricultural enterprise put input dealers at the forefront. It is therefore essential to strengthen the advisory role being performed by input dealers towards bridging the shortage of public agricultural extension services in the country.

Owoade and Akinwale (2019) reported that poultry input dealers provide extension services to commercial poultry farmers in Ogbomoso Agricultural Zone of Oyo State in Nigeria. Input dealers are located close to farmers than Village Extension Agents (VEAs), so they sell inputs to farmers, provide advice on use and act as opinion leaders (Ganiger, 2012). In Nigeria, input dealers are regarded as strategic partners in getting rid of corruption associated with Federal and State governments' input procurement and distribution (Coker, 2014). Therefore, input dealers are strategically placed to advise farmers on the use of inputs for enhanced productivity. This is expected as advisory services are delivered to farmers as embedded services (Swanson and Rajalahti, 2010). Moreover, the strategically positioned input dealers are always in contacts with farmers in their localities to advise them. If the input dealers fail in this responsibility farmers will use most inputs wrongly. Inappropriate use of chemicals by farmers has caused physical and chemical degradation of the soil, water pollution and food contamination (Argade et al., 2015). It thus poses danger to farmers, consumers and the environment.

Please cite as: Owoade E.O., Abubakar M., Abdulhakeem A.L. and Akinwale J.A. (2022). Factors influencing input dealers' performance of extension roles to farmers in Yobe State of Nigeria. Agro-Science, 21 (1), 98-102. DOI: https://dx.doi.org/10.4314/as.v21i1.15 
The primary goal of input distribution is profit making but sustenance of sales depends on farmers' favourable evaluation of inputs after use. Hence, educating and guiding farmers offer twofold advantage to both input dealers and farmers as input dealers can sell more inputs while farmers apply knowledge and achieve growth in production. Studies have revealed that some countries exploited the strategic positions occupied by input dealers to create initiatives for capacity building (Ganiger, 2012). In such countries, input dealers were trained to capacitate them for better performance of advisory roles since most of them did not possess qualifications and skills of public extension agents (Ganiger, 2012). This implies that input dealers need to acquire technical and communication skills like the extension agents to effectively disseminate agricultural information (Tsebee, 2017). A study on the input dealers' performance of extension roles or factors influencing the performance of extension roles is yet to be documented in Yobe State to the best of our knowledge. Factors such as low literacy rate and high poverty index (UNESCO, 2012; OPHI Country Briefing, 2017) and inadequate public extension service in Yobe State prove the timeliness of this research. The general objective of the study was to identify the factors influencing input dealers' performance of extension roles in Yobe State. The specific objectives were to: describe the socioeconomic characteristics of input dealers in the study area; ascertain the extent of performance of extension roles by input dealers; identify the input dealers' sources of agricultural knowledge; and examine the trainings that the input dealers undergo to enhance their capacity to perform extension roles. The following hypotheses stated in null forms were tested in this study: 1). There is no significant relationship between socioeconomic characteristics and performance of extension roles; 2). There is no significant relationship between sources of knowledge and performance of extension roles; and 3) There is no significant relationship between training and performance of extension roles.

\section{MATERIALS AND METHODS}

The study was carried out in Yobe State which is one of the northeastern states in Nigeria. The state, which was created from the western part of Borno in 1991, is bounded on the north by Niger Republic and on the east by Borno State. Also, it borders Gombe State to the southwest, Bauchi to the west and Jigawa State to the northwest. Its vegetation is predominantly Sudan Savannah with characteristic scattered acacia trees. There is also a fringe of Sahel Savannah in the far north with sandy soil type and grown over by thorn scrub. Yobe land consists of plain drained seasonally by Komadugu River and its tributaries in the north and by the Gongola River in the south. The State lies between latitude $12^{\circ} 00^{\prime} \mathrm{N}$ and longitude $11^{\circ} 30^{\prime} \mathrm{E}$, covering a land area of about 45,502 square kilometers (Galadima, 2014). The 2016 population estimate of the State was put at 3,294,137 people (NBS, 2017). Kanuri people are the largest ethnic group in the state and hausa language is widely spoken. Damaturu is the state capital, and Nguru, Potiskum, and Gashua are sizeable market towns (Encyclopedia Britanica, 2020). As an agrarian state where agricultural production remains the largest source of employment and income, primary crops such as rice, sorghum, millet, peanuts (groundnuts), cowpeas, corn (maize), sesame, and cotton are cultivated. Livestock such as cattle, sheep and goats are also herded by pastoralists.

The population for this study was all input dealers in Yobe State Nigeria. Multi-stage sampling procedure was adopted in selecting 86 input dealers. First stage involved purposive selection of four major towns which are Damaturu, Potiskum, Gashua and Nguru known to have big markets and high presence of input dealers. List of input dealers was compiled from each selected town by enumerators who traversed every nook and cranny using snowball technique. On four separate lists, Damaturu had 25 inputs dealers; Potiskum had 33 input dealers while Gashua and Nguru had 30 and 20 input dealers respectively. In the second stage, $80 \%$ of the input dealers were selected from the list using simple random sampling. This procedure led to the selection of 20,26, 24 and 16 input dealers from Damaturu, Potiskum, Gashua and Nguru respectively. A total of 86 input dealers were finally selected as respondents.

A structured questionnaire was used to collect primary data for the study. Performance of extension roles was measured by asking the input dealers to indicate the extent to which they perform various extension roles on a three-point rating scale of 'Always', 'Occasionally' and 'Never' with scores of 2, 1 and 0 respectively. The critical value was calculated as $2+1+0 / 3=1$; therefore, any value of performance of extension role $\geq 1$ implies high performance while any value of performance of extension role $<1$ implies low performance. Sources of agricultural knowledge was measured by asking the input dealers to indicate various sources of agricultural knowledge they are exposed to in which each source attracts score of 1 point and total was calculated. Training received was measured by asking the input dealers to indicate the extent to which they were trained by each actor of Agricultural Knowledge System on five-point rating scale of 'monthly', 'every three months', 'twice a year', 'once a year', and' no training' with scores of $4,3,2,1$ and 0 respectively. Critical value was calculated as $4+3+2+1+0 / 5=2$; hence, any value of training $\geq 2$ implies high training while any value of training $<2$ implies low training. Data 
were analyzed using descriptive and inferential statistical tools. Descriptive tools used are means, frequency counts and percentages while inferential tools used are Pearson Product Moment Correlation and Chi-square at the 0.05 level probability.

\section{RESULTS AND DISCUSSION}

\section{Socioeconomic Characteristics of Input Dealers}

Results in Table 1 show that $30.0 \%$ of input dealers were within the age range of 31 and 40 years while $31.4 \%$ were within 41 and 50 years. The mean age was 41.8 years. This implies that the input dealers were mainly middle-aged people, hence they could contribute significantly to agricultural development through input distribution. This finding is in line with the finding of (Ganiger, 2012) who reported that input dealers were mostly individuals in their middle age. The results further show that majority $(98.8 \%)$ were male. The business of input distribution was dominated by male sex. The finding is in consonance with the finding of Etyang et al. (2015) who stated that more male input dealers than females were involved in extension role. Furthermore, the table shows that $44.2 \%$ of the input dealers had tertiary education. This finding is in consonance with Adam (2018) who found that $20.8 \%$ agro-input dealers in northwest Nigeria attained tertiary education. It is expected that with their level of education they should be able to provide information to farmers. The table also shows that majority $(86.0 \%)$ of input dealers did not have agricultural education. This implies that they lack theoretical background knowledge in agriculture. The finding agrees with that of Argade et al. (2015) who found that most male input dealers did not possess agricultural qualification. Table 1 reveals that $32.2 \%$ of input dealers had between 1 and 10 years of experience as input dealers and similarly $32.2 \%$ had between 11 and 20 years of experience. The mean year of experience was 15.9 years. This implies that inputs dealers had a long period of experience and would be familiar with customers' input acquisition and information seeking behaviour. Result in Table 1 on membership of input dealers association shows that majority $(60.5 \%)$ of input dealers belonged to input dealers association. The implication is that membership will present robust platform to capacitate input dealers for enhanced performance of extension functions. Table 1 further reveals that majority $(84.9 \%)$ of input dealers owned farms as another source of income. Result on types of business reveals that $48.8 \%$ was involved in retail business while $47.7 \%$ had a mix of retail and wholesale business. Furthermore, result on types of inputs supplied by the input dealers reveal that $61.0,73$ and $78 \%$ of input dealers were involved in the sales of seeds, fertilizers and pesticides respectively. Only $37.2 \%$ of input dealers were involved in selling machines and equipment.
Table 1: Distribution of socio-economic characteristics of input dealers

\begin{tabular}{|c|c|c|c|}
\hline Variable & & Frequency & $\%$ \\
\hline \multirow[t]{6}{*}{ Age (years) } & $21-30$ & 13 & 15.1 \\
\hline & $31-40$ & 30 & 34.9 \\
\hline & $41-50$ & 27 & 31.4 \\
\hline & $51-60$ & 11 & 12.8 \\
\hline & $61-70$ & 05 & 5.8 \\
\hline & Mean & 41.8 & \\
\hline \multirow[t]{10}{*}{ Sex } & Male & 85 & 98.8 \\
\hline & Female & 01 & 1.2 \\
\hline & Level of education & & \\
\hline & No formal education & 17 & 19.8 \\
\hline & Primary & 05 & 5.8 \\
\hline & Secondary & 26 & 30.2 \\
\hline & Tertiary & 38 & 44.2 \\
\hline & Area of specialization & & \\
\hline & Agriculture & 12 & 14.0 \\
\hline & Non-agriculture & 74 & 86.0 \\
\hline \multirow{6}{*}{$\begin{array}{l}\text { Years of } \\
\text { experience as } \\
\text { input dealers }\end{array}$} & $1-10$ & 32 & 37.2 \\
\hline & $11-20$ & 32 & 37.2 \\
\hline & $21-30$ & 18 & 20.9 \\
\hline & $31-40$ & 03 & 3.5 \\
\hline & $41-50$ & 01 & 1.2 \\
\hline & Mean & 15.9 & \\
\hline \multirow{2}{*}{$\begin{array}{l}\text { Membership of } \\
\text { input dealers } \\
\text { association }\end{array}$} & Members & 52 & 60.5 \\
\hline & Non-members & 34 & 39.5 \\
\hline \multirow[t]{2}{*}{ Farm ownership } & Owned farm & 73 & 84.9 \\
\hline & Did not own farm & 13 & 15.1 \\
\hline \multirow[t]{3}{*}{ Types of trade } & Retail & 42 & 48.8 \\
\hline & Retail and wholesale & 41 & 47.7 \\
\hline & Wholesale & 03 & 3.5 \\
\hline \multirow[t]{4}{*}{ *Types of inputs } & Seeds & 61 & 70.9 \\
\hline & Fertilizers & 73 & 84.9 \\
\hline & Pesticides & 78 & 90.7 \\
\hline & $\begin{array}{l}\text { Machines and } \\
\text { equipment }\end{array}$ & 32 & 37.2 \\
\hline
\end{tabular}

Source: Field Survey, 2020. * Multiple responses

Input Dealers' Performance of Extension Roles Results in Table 2 show that performance of extension roles was high for selling of inputs ranked $1^{\text {st }}(\overline{\mathrm{x}}=1.55)$ and providing information on safe use of chemicals ranked $2^{\text {nd }}(\overline{\mathrm{x}}=1.40)$. Also, it was high for provision of information on rate of application of chemicals ranked $3^{\text {rd }}(\overline{\mathrm{x}}=1.36)$ as well as provision of information on choice of fertilizers ranked $4^{\text {th }}(\bar{x}=1.29)$. Performance of extension role of linking farmers to sources of credits $(\bar{x}=0.49)$, linking farmers to extension agents $(\overline{\mathrm{x}}=0.52)$ and providing information on machines and equipment $(\overline{\mathrm{x}}=0.72)$ was low.

\section{Distribution of Input Dealers according to Performance of Extension Roles}

Table 3 shows that the performance of extension roles of more than half $(55.8 \%)$ of the input dealers was high. This implies that many input dealers were highly involved in extension duties. Therefore, there is high prospect of improved performance of extension roles by input dealers to complement the effort of public extension, which currently is inadequate and inefficient. This finding is supported by the finding of DAESI (2019) who reported that input dealers were the main providers of information for farmers. 
Table 2: Input dealers' performance of extension role

\begin{tabular}{llllll}
\hline S/N & Activities & Mean $(\overline{\mathrm{x}})$ & Std. dev. & Rank & Remarks \\
\hline 1. & Selling inputs & 1.55 & 0.50 & $1^{\text {st }}$ & High performance \\
2. & Fertilizer related: Providing information on choice of fertilizers & 1.29 & 0.61 & $4^{\text {th }}$ & High performance \\
3. & Provide information on application rate & 1.20 & 0.65 & $5^{\text {th }}$ & High performance \\
4. & Chemical related (e.g., pesticide, herbicides): & 1.20 & 0.55 & $6^{\text {th }}$ & High performance \\
& Providing information on choice of chemicals & 1.36 & 0.59 & $3^{\text {rd }}$ & High performance \\
5. & Providing information on rate of application & 1.40 & 0.67 & $2^{\text {nd }}$ & High performance \\
6. & Providing information on safe use of chemicals & 1.04 & 0.65 & $7^{\text {th }}$ & High performance \\
7. & Seed related: Providing information on variety of seeds & 0.77 & 0.71 & $9^{\text {th }}$ & Low performance \\
8. & Providing information on seed planting and spacing & 0.72 & 0.70 & $10^{\text {th }}$ & Low performance \\
9. & Providing information on machines and equipment & 0.78 & 0.62 & $8^{\text {th }}$ & Low performance \\
10. & Selling to farmers on credit & 0.49 & 0.63 & $12^{\text {th }}$ & Low performance \\
11. & Linking farmers to sources of credit & 0.52 & 0.61 & $11^{\text {th }}$ & Low performance \\
12. & Linking farmers to extension agents & &
\end{tabular}

Table 3: Distribution of input dealers according to performance of extension

\begin{tabular}{lcc}
\hline Performance of extension role & Frequency & Percentage \\
\hline High performance & 48 & 55.8 \\
Low performance & 38 & 44.2 \\
Total & 86 & \\
Mean $=12.30$ & & \\
\hline
\end{tabular}

Source: Field Survey, 2020

Input Dealers' Sources of Agricultural Knowledge Results on input dealers' sources of agricultural knowledge show that the source of agricultural knowledge of majority $(70.9 \%)$ was farm experience (Table 4). Furthermore, 59.3\%, 55.8\% and 52.3\% had radio, input companies and the internet as their sources of agricultural knowledge respectively. Half $(50.0 \%)$ of the input dealers had extension agents as their sources of agricultural knowledge. This implies that the input dealers obtain agricultural knowledge from different sources. The reliance of input dealers on different sources of agricultural knowledge will more likely enhance their capacity to perform extension role to farmers.

Table 4: Input dealers' sources of agricultural knowledge

\begin{tabular}{llll}
\hline S/N & $\begin{array}{l}\text { *Sources of agricultural } \\
\text { knowledge }\end{array}$ & Frequency & Percentage \\
1. & Agricultural books & 27 & 31.4 \\
2. & Extension agents & 43 & 50.0 \\
3. & Radio & 51 & 59.3 \\
4. & Television & 35 & 40.7 \\
5. & Farm magazine & 20 & 23.3 \\
6. & Internet & 45 & 52.3 \\
7. & Farm experience & 61 & 70.9 \\
8. & Input companies & 48 & 55.8 \\
9. & Other input dealers & 37 & 43.0 \\
10. & Training/workshop & 29 & 33.7 \\
11. & Non-governmental & 02 & 2.3 \\
& organizations & & \\
\hline
\end{tabular}

Source: Field Survey, 2020. * Multiple responses

\section{Training Received by the Input Dealers}

Results on training received by the input dealers in Table 5 from various actors of Agricultural Knowledge System show that input dealers organisation ranked $1^{\text {st }}(\overline{\mathrm{x}}=0.81)$ as provider of training to input dealers. Chemical companies ranked $2^{\text {nd }}(\overline{\mathrm{x}}=0.72)$ and extension agency ranked $3^{\text {rd }}(\overline{\mathrm{x}}=0.61)$ as trainers. Given that the mean of training from each of the actors was less than 2.0, it implies that training received was generally low.

Distribution of Input Dealers on Training Received Distribution of input dealers based on training received shows that the majority $(68.6 \%)$ of them had low training (Table 6). This implies that these input dealers would not be able to perform extension roles effectively with low training. This finding is in agreement with DAESI (2019) that most input dealers did not have formal training on selection and use of agro-inputs.

Test of Relationship between Independent Variables and Performance of Extension Role

Table 7 shows that a significant positive correlation existed between performance of extension roles and training received $(r=0.33, p<0.05)$. This implies that the more the input dealers are trained in agriculture the better their performance. This finding agrees with Leelavani (2011) who reported a positive relationship between training received and information output behaviour of input dealers. Also, a significant positive correlation existed between performance of extension roles and sources of agricultural knowledge $(r=0.25, p<0.05)$. So, the more the sources of knowledge used by input dealers the more they performed extension roles.

Table 5: Training received by the input dealers

\begin{tabular}{|c|c|c|c|c|c|}
\hline $\mathrm{S} / \mathrm{N}$ & Activities & Mean $(\overline{\mathrm{x}})$ & Std. dev. & Rank & Remarks \\
\hline 1. & Seed companies & 0.59 & 0.93 & $4^{\text {th }}$ & Low training \\
\hline 2. & Chemical companies & 0.72 & 1.09 & $2^{\text {nd }}$ & Low training \\
\hline 3. & Extension agency (ADP) & 0.61 & 1.04 & $3^{\text {rd }}$ & Low training \\
\hline 4. & Research institute & 0.34 & 0.79 & $5^{\text {th }}$ & Low training \\
\hline 5. & Non-governmental organization & 0.08 & 0.41 & $6^{\text {th }}$ & Low training \\
\hline 6. & Input dealers' organization & 0.81 & 1.06 & $1^{\mathrm{st}}$ & Low training \\
\hline
\end{tabular}


Table 6: Distribution of input dealers based on level of training received

\begin{tabular}{lcc}
\hline Training & Frequency & Percentage \\
\hline High training & 27 & 31.4 \\
Low training & 59 & 68.6 \\
Total & 86 & \\
Mean $=4.04$ & & \\
\hline
\end{tabular}

Source: Field Survey, 2020

Table 7: Correlation analysis of some variables and performance of extension role

\begin{tabular}{lllll}
\hline Variables & r-value & p-value & Decision & Remark \\
\hline Training received & 0.33 & $0.00 *$ & $\mathrm{~S}$ & Reject \\
Knowledge sources & 0.25 & $0.02 *$ & $\mathrm{~S}$ & Reject \\
Age & 0.03 & 0.82 & $\mathrm{NS}$ & Accept \\
Years of experience & -0.01 & 0.94 & $\mathrm{NS}$ & Accept \\
as inputs supplier & & & \\
\hline Source: Data Analysis, 2020. *Significant at & $p<0.05$ (2- tailed). \\
S - significant, NS - not significant
\end{tabular}

Table 8: Chi-square analysis of some variables and performance of extension role

\begin{tabular}{lccccc}
\hline Variables & $\chi 2$ & df & $p$ & Decision & Remark \\
\hline Level of educ. & 9.162 & 4 & 0.057 & NS & Accept \\
Type of trade & 25.135 & 2 & $0.000 *$ & S & Reject \\
Membership of & 12.550 & 1 & $0.000 *$ & S & Reject \\
input dealers assoc. & & & & & \\
\hline & Source: Data Analysis, 2020. *Significant at $p<0.05$ & (2- tailed). \\
S - significant, NS - not significant & & &
\end{tabular}

Furthermore, Chi-square $\left(\chi^{2}\right)$ analysis in Table 8 shows that there was a significant relationship between type of trade $\left(\chi^{2}=25.135, p<0.05\right)$ and performance of extension role. This means that type of trade has influence on performance of extension roles. There existed a significant relationship between the input dealers' membership of input dealers association $\left(\chi^{2}=12.550, p<0.05\right)$ and performance of extension roles. This implies that membership of association influences performance of extension roles.

\section{CONCLUSION/RECOMMENDATIONS}

The study concluded that input dealers are mostly males; middle aged, educated but had no agricultural qualifications. They had substantial years of experience as input dealers and were also farm owners. Although, input dealers' performance of extension roles was high but they had low training to boost performance. They had access to multiple sources of agricultural knowledge of which farm experience was primary. Training, sources of agricultural knowledge, type of trade and membership of input dealers association influenced performance of extension roles. Therefore, input dealers should be strengthened to perform extension role by enhancing training and access to multiple sources of agricultural knowledge via institutionalized research, extension, input companies and input dealers' linkage.

\section{REFERENCES}

Adam A.O. (2018). Role of men and women in agro-input business in Northwest Nigeria. J. Agric. Ext., 22 (1), 15-21

Agbamu J.U. and Okagbare G.O. (2005). Institutional strengthening of Ogun State ADP upon expiration of World Bank assistance. In: Orheruata A.M. et al. (eds.), Agricultural Rebirth for Improved Production in Nigeria (pp. 322-325). Proc. 39th Ann. Conf. Agric. Soc. Nig., University of Benin, 9-13 Oct., Benin City
Anderson J.R. (2008). Innovating through Science and Technology. A Background Paper of the WDR, Agric. \& Rural Dev. Dept, World Bank, Washington, DC

Argade S., Sarkar A. and Mishra S. (2015). Gender based involvement of agro-input dealers in extension activities in Maharashtra State, India. Int. J. Agric. Sci., 7 (3), 470-473

Coker A.A. (2014). Determinants of agro-inputs redemption under the electronic wallet initiative in Nigeria. Agro-Science, 13 (2), 24-36

DAESI (2019). Capacity Development of Agricultural Input Dealers in India through the DAESI Programme. Good Practice Notes, 2. Available at www.aesanetwork.org

Encyclopedia Britannica (2020). Yobe State, Nigeria. www.britannica.com/place/Yobe

Etyang T.B., Okello J.J., Zingore S., et al. (2015). Exploring the relevance of agro-input dealers in disseminating and communicating of soil fertility management knowledge: The case of Siaya and Trans Nzoia counties. Agric. Inform. Worldwide, 6, 82-95

Galadima M. (2014). Constraints on farmers access to agricultural information delivery: A survey of rural farmers in Yobe State, Nigeria. IOSR J. Agric. Vet. Sci., 7 (9), 18-22

Ganiger S. (2012). Knowledge, Perception and Role Performance of Input Dealers in Agro Advisory Services in Northern Dry Zone of Karnataka. MSc Thesis, Dept. of Agric. Extension, Acharya NG Ranga Agricultural University, Hyderrabad, India. Available at https://krishikosh.egranth.ac.in/handle/1/66814

Haruna S.K. and Abdullahi Y.M.G. (2013). Training of public extension agents in Nigeria and the implications for government's agricultural transformation agenda. J. Agric. Ext., 17 (2), 98-104

Leelavani M. (2011). A study on communication behavior of input dealers in Guntur District of Andhra Pradesh. B.Sc. Thesis, Acharya NG Ranga Agricultural University, Hyderrabad, India, Available at http://krishikosh.egranth.ac.in/handle/1/66692

Madukwe M.C. (2008). Practice without Policy: The Nigeria Agricultural Extension Service. An Inaugural Lecture (pp. 5-12), University of Nigeria, 29 Apr.

NBS (2017). Demographic Statistics Bulletin. Available at https://africanopendata.org/dataset/demographicstatistics-bulletin-nigeria-2017

Ogunlade I., Atibioke O.A., Ladele A.A. and Adumadehin G.S. (2012). Capacity of agro-input dealers in advisory service delivery to maize farmers in Kwara State, Nigeria. Int. Res. J. Agric. Sci. Soil Sci., 2 (10), 426-443

OPHI Country Briefing (2017). Global Multidimensional Poverty Index (MPI) at a glance. Available online at www.dataforall.org

Owoade E.O. and Akinwale J.A. (2019). Poultry farmers' perception of extension services delivery through input providers in Ogbomoso Zone of Oyo State, Nigeria. South Afr. J. Agric. Ext., 47 (1), 36-44

Swanson B.E. and Rajalahti R. (2010). Strengthening Agricultural Extension and Advisory Systems: Procedures for Assessing, Transforming and Evaluating Extension Systems. The Int. Bank for Reconstr \& Dev./The World Bank, Agric. \& Rural Dev. Disc. Paper No. 44

Tsebee K.A. (2017). Enduring Issues in Extension Communication for Rural Development in Nigeria. Ibadan Nigeria: Prime Publ. \& Educ. Serv., p. 89

UNESCO (2012). Reaching the 2015 Literacy Target: Delivering on the Promise. High Level International Round Table on Literacy, Action Plan Nigeria National Literacy Action Plan for 20122015UNESCO, Paris, 6-7 Sep., www.unesco.org 